\title{
ASSESSMENT OF SOIL EROSION ON HILLSLOPES (A CASE STUDY CARRIED OUT IN THE ASHAN DRAINAGE BASIN, IRAN)
}

\author{
H. SADOUGH VANINI* and MOSTAFA AMINI
}

\author{
Department of Physical Geography, Faculty of Earth Sciences, Shahid Beheshti University, Tehran, Iran \\ *Corresponding author: h-sadough@sbu.ac.ir
}

\section{ABSTRACT}

The objective of this study is to determine the rate of soil erosion on slopes of differing steepness and its effects on agricultural land and pastures in the drainage basin around Ashan. Exogenous factors like water and wind and endogenous elements such as erodibility of the soil have key roles in erosion and the results of this study will help in the management of soil and soil conservation programs. Soil erosion in the drainage basin around Ashan has accelerated and because of this it is important to determine the erodibility of the soil. In this study, the soil on four different hill slopes was sampled and after drying, soil size distribution and soil texture and the organic content of forty samples, and the k-factor (erodibility) using the USLE equation, were determined. According to the results of the ANOVA test there are strong relationships between the variables, which is illustrated by box plots. The results indicate that erodibility is significantly $(p<$ 0.05 ) associated with the type of land use and landforms. The highest levels of erosion were recorded on the back-slope and the least at the summit and on the toe-slope. Discriminant function analysis was used to determine the discriminatory power of the erodibility factor associated with the different uses of land and landform components. According to the DFA results, the K factors indicate the use of the land and landforms were the most significant factors, with significances of 0.000 and 0.002 , respectively.

Keywords: erodibility, k-factor, Ashan drainage basin, Universal Soil Loss Equation

\section{Introduction}

Erosion is closely associated with an irreversible reduction in the amount of soil and its productivity and results in irreparable damage to the environment. In Iran, 8 to 16 tons of agricultural soil are annually made useless due to erosion. Erosion rates reached 800 percent between 1951-2001 (Nosrati 2011). The accumulation of sediment behind dams equals about 120 million hectares per year, indicating a decrease in the lifetime of dams of about 1 to $2 \%$ (IWRM 2009). For the prevention of soil erosion, therefore, it is necessary to reduce the rate of erosion as it is considered to be one of the most critical factors in terms of protecting and managing natural resources (Agassi 1996). This requires the recognition of the factors that contribute to erosion, prediction of the degree of soil erosion and the provision of proper solutions.

Many models can predict soil erosion, among which the Universal Soil Loss Equation (USLE) is the most common and widely used to estimate the amount of erosion by water. According to this model, one of the six factors affecting this kind of erosion is the erodibility of soil. This model includes: soil loss (A), a rainfall erosivity factor $(\mathrm{R})$, soil erodibility factor $(\mathrm{K})$, length of the hillslope $(\mathrm{L})$, gradient $(\mathrm{S})$, vegetation $(\mathrm{C})$ and conservation practices (P) (Renard et al. 1997).

According to Veihe et al. (2003), erodibility of soil is the inherent sensitivity of soil to erosion and the separating of soil particles due to the kinetic energy of rain and their transport by rain water. Based on the results of extensive studies in various parts of the world, soil erodibility is determined by five soil characteristics, namely the percentage of sand, total percentage of very fine silt and sand, organic matter content and permeability of the soil profile (Veihe et al. 2003). In the vegetated areas of the planet, geomorphic and hydrologic processes, which involve the transport of hillslope sediment, are very dependent on soil properties. Such effects are recognized in the theoretical paper of Chorley (Chorley 1959), but in practice, the dynamic and complex effects of the properties of shallow soil on the removal of sediments by water from hillslopes are neglected by geomorphologists. Although the hydraulic conditions determine the surface flow of erosive forces working on the soil, soil properties change these conditions and finally they all contribute to the uneven terrains (hillslopes) (Bryan 1991). The K-factor reflects the soil separability during rainfall or surface flow and soil shift per unit of soil caused by external forces. This factor is related to the combined effect of rainfall, runoff and soil permeability and is a consequence of the effect of soil properties on soil loss due to rain and is derived by using the USLE nomograph (Wischmeier 1978). However, the effect of soil properties on erodibility in different parts of a hillslope with various aspects and different usages in different parts of the world is unknown and therefore more research is required in this field.

There are abundant deposits behind the Alavian Dam in the Ashan drainage basin north of the city of Maragheh (Fig. 1), which are the result of soil erosion. However, conservation management needs to know what the resistance of soil is to erosion, that is, the erodibility of soil, which in this region is unknown; given the above facts, identifying the erodibility $(k)$ in different parts of hillslopes subject to various kinds of land use is one of the main goals of this study that aims to reduce the accumulation of sediment in the reservoir and detect the spatial variations in soil erosion in the Ashan drainage basin. 
Bennett (1926) started research on soil properties related to erosive resistance in Cuba and Middleton (1903) formulated the concepts of erodibility and provided two erodibility indexes, which incorporated runoff characteristics and soil particle separability, which are dependent on the behaviour of soils in California (Middleton 1903; Bennett 1926), but from 1960 to the present, numerous studies (Smith and Wischmeier 1962; Bryan 1968; De Ploey 1985; Romkens 1985; Lal 1990; Bryan 1991) have tested, developed, replaced or corrected these indexes as universal indexes of erodibility. In the research done by Kirkby and Morgan (1980), the effect of mineral particles on soil erosion is demonstrated (Kirkby and Morgan 1980). Young et al. (1990) review the data from US Agricultural Stations and conclude that the $\mathrm{K}$-factor is at a maximum following snow melt and decreases markedly at the end of the growing season. According to their results, the effects of the physical and chemical characteristics of soil and other parameters such as soil depth and vegetation on the rate of soil erosion is dependent on the relationship between these elements. Ghoddousi and Ghaderi (2005) in their study on the Telvarchay drainage basin in Kurdistan conclude that soil erosion increases with increase in the clay to sand and silt ratio (Ghaderi and Ghoddosi 2005). On the other hand, studies in Iran indicate a strong relationship between soil erosion and soil management (Bahrami et al. 2005), soil texture and organic matter and organic matter content and lime content (Nosrati et al. 2011).

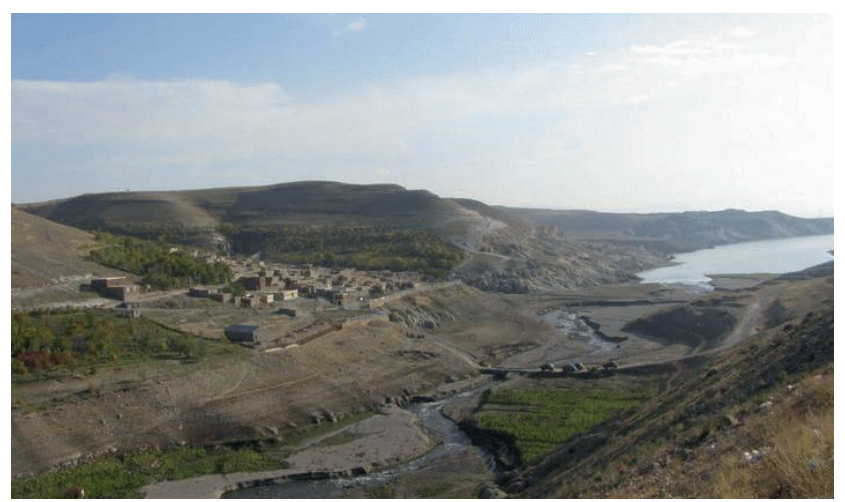

Fig. 1 Sediments behind the Alavian Dam at the exit of the Ashan drainage basin.

\section{Materials and Methods}

\section{Study area}

The present research was conducted in the Ashan drainage basin, which covers an area of 320 square kilometers in the County of Maragheh in South East Azerbaijan (Fig. 1). According to the Demarton climate classification, this region has a cold and dry climate (climatology map of Iran, 2014). The region has an average annual rainfall of $360 \mathrm{~mm}$ and average annual temperature of $7.8-12.5^{\circ} \mathrm{C}$. The city covers an area of approximately 840 square kilometers and only accounts for $8.1 \%$

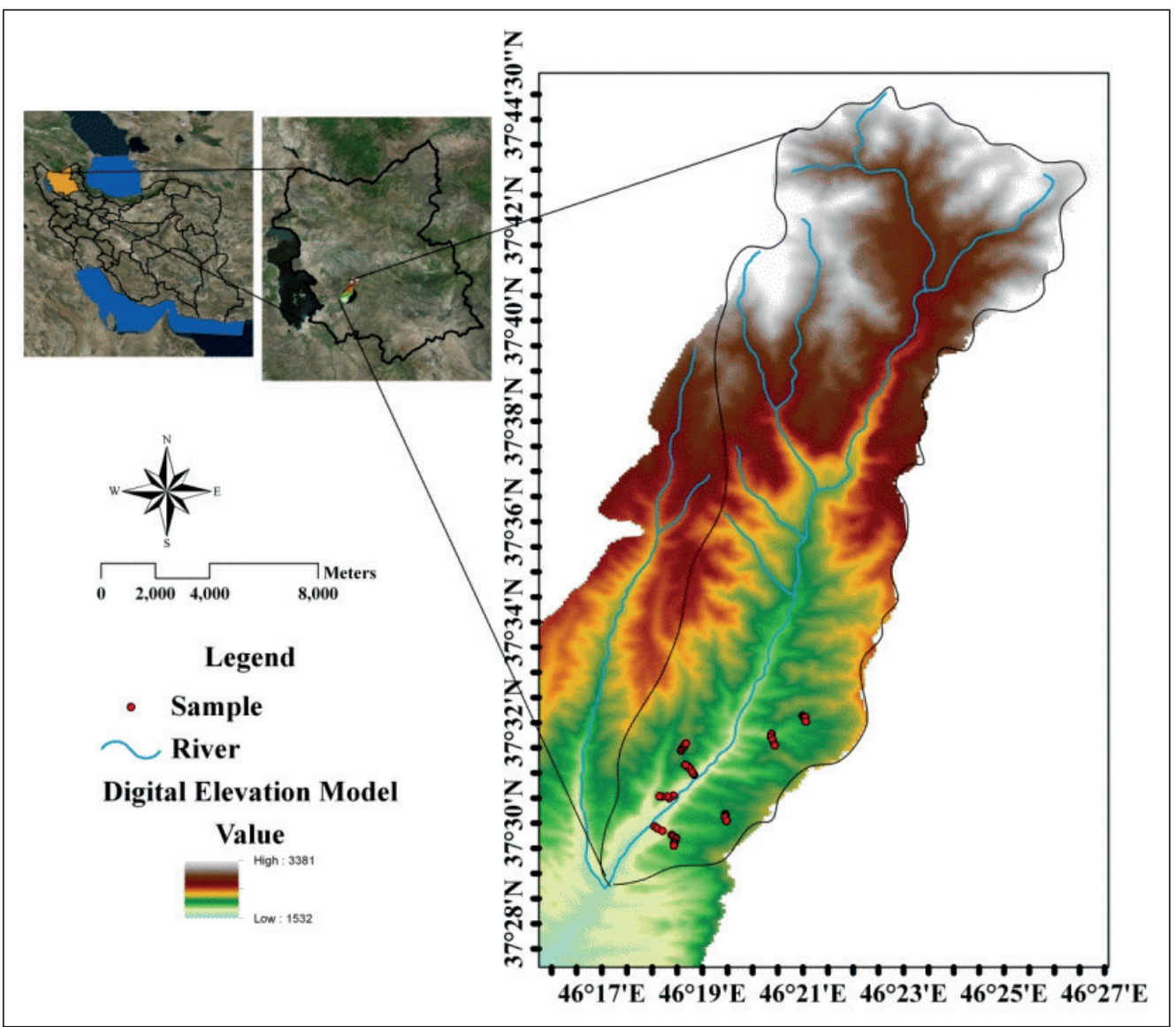

Fig. 2 Geographical location of Ashan drainage basin (National Cartography Organization of Iran 2011). 


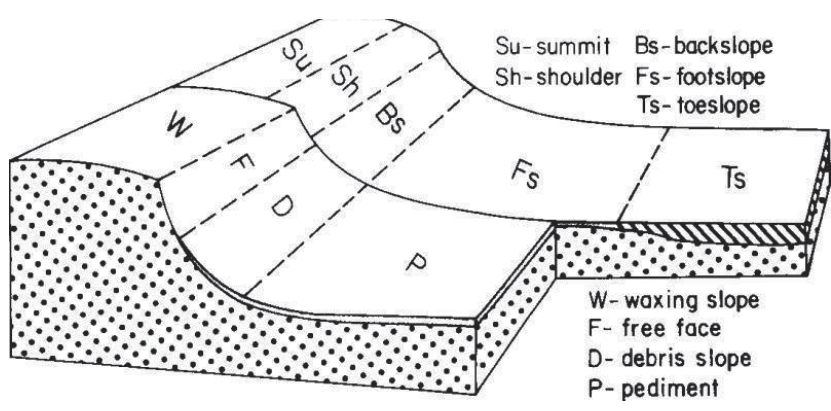

Fig. 3 Landform positions of a hill-slope (Ruhe 1960).

of the total area of the province. The altitude in the region is $1290 \mathrm{~m}$ above sea level in the west and up to $2000 \mathrm{~m}$ in the north and most of the region is at an altitude of less than $1700 \mathrm{~m}$. Total area of cultivated land in the study area is $60 \mathrm{~km}^{2}$. Dry farming is the dominant agriculture method in this region. In terms of agrology, soils in the region fall within the range of Loam-Clay Loam with an electrical conductivity of 2-16 decisiemens.

\section{Sampling and laboratory analysis of soil samples}

Maps of the geographical location, topography and land use were prepared using Geographical Organization maps with a scale of 1: 50,000 (Fig. 2). Since soil erosion is affected by land use and erodibility is not independent of the land use and is influenced by the amount of organic matter, soil structure and permeability (Nosrati et al. 2011), 40 soil samples were collected in a random way. Soils were sampled at a depth of $15 \mathrm{~cm}$ and collected from agricultural and pastoral land on four hillslopes. Five positions on the hillslopes with four different aspects based on the classification of Ruhe (1960) (Fig. 3) were sampled (Table 1). The positions were the summit, shoulder, back slope, foot slope and toe slope. The erodibility of the soil was determined as mentioned in treatments. The sampling at the five positions on the hillslopes started on October 30, 2014 and ended on November 6, 2014 In the sampling process GPS was used to determine the exact location at which a sample was collected (Fig. 4). The parameters recorded during sampling were: latitude and longitude in degrees, minutes and seconds, altitude above sea level, land use, hillslope aspect, position on hillslope, local name of the location and date sampled. The samples were taken to the laboratory.

In the laboratory, samples were first dried in an oven at $120^{\circ} \mathrm{C}$ for 24 hours. After drying, they were pressed and then weighed. In order to determine the content of very fine sand, one of the parameters required for the calculation of the K-factor, a sieve-shaker device with a $2 \mathrm{~mm}$ mesh size was used. The soil texture (clay $(<0.002 \mathrm{~mm})$, silt $(0.002-0.05)$ and sand $(0.05-2 \mathrm{~mm}))$ were determined

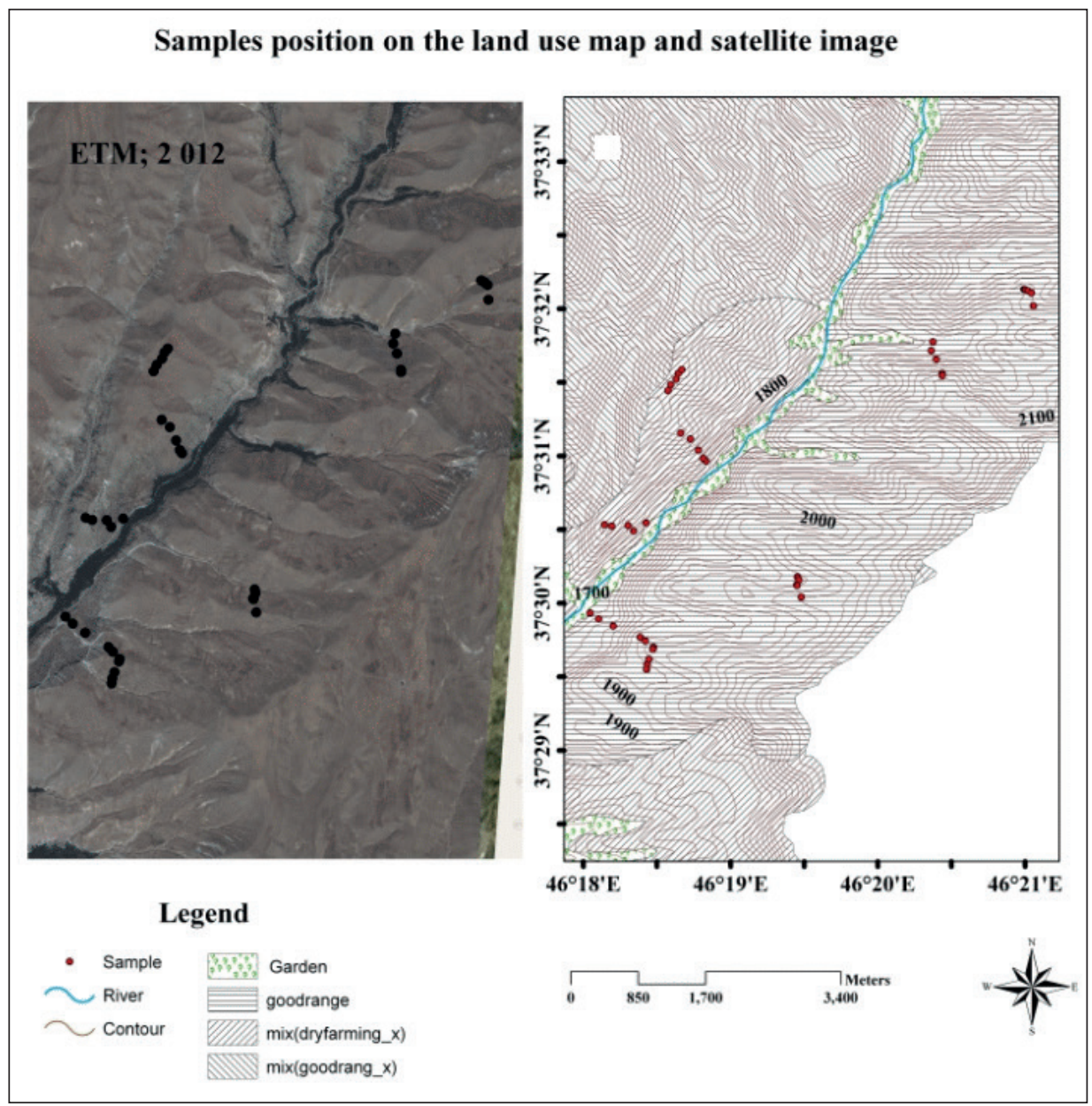

Fig. 4 Locations for the samples collected from the Ashan drainage basin. 
Tab. 1 The laboratory analysis of the soil samples collected from different positions on hillslopes subject to different land uses in the Ashan drainage basin.

\begin{tabular}{|c|c|c|c|c|c|c|c|c|c|c|c|c|}
\hline Land use & Direction & $\begin{array}{l}\text { Hill slope } \\
\text { position }\end{array}$ & $\begin{array}{l}\text { Local } \\
\text { name }\end{array}$ & $\begin{array}{l}\text { Sampling } \\
\text { date }\end{array}$ & $\begin{array}{c}\text { Clay } \\
\%\end{array}$ & $\begin{array}{l}\text { Silt } \\
\%\end{array}$ & $\begin{array}{c}\text { Sand } \\
\%\end{array}$ & $\begin{array}{c}\text { Very } \\
\text { fine } \\
\text { sand \% }\end{array}$ & $\begin{array}{c}\text { Structure } \\
\text { code }\end{array}$ & $\begin{array}{c}\text { Organic } \\
\text { mater \% }\end{array}$ & $\begin{array}{l}\text { Texture } \\
\text { code }\end{array}$ & $\begin{array}{c}K \\
\text { factor }\end{array}$ \\
\hline Agriculture & North & summit & Ashan & $06 / 11 / 2014$ & 9.28 & 35.28 & 55.44 & 16.63 & 1 & 1.99 & 2 & 0.29 \\
\hline Agriculture & North & shoulder & Ashan & $06 / 11 / 2014$ & 10.56 & 42.72 & 46.72 & 14.02 & 1 & 1.1 & 4 & 0.35 \\
\hline Agriculture & North & Back slope & Ashan & $06 / 11 / 2014$ & 25.28 & 38 & 36.72 & 11.02 & 4 & 0.01 & 6 & 0.36 \\
\hline Agriculture & north & Foot slope & Ashan & $06 / 11 / 2014$ & 8.16 & 27.44 & 64.4 & 9.32 & 2 & 0.63 & 3 & 0.25 \\
\hline Agriculture & North & Toe slope & Ashan & $06 / 11 / 2014$ & 27.28 & 41.64 & 31.08 & 9.32 & 2 & 0.85 & 2 & 0.27 \\
\hline Agriculture & South & summit & Ashan & $03 / 11 / 2014$ & 15.28 & 18 & 66.72 & 20.02 & 3 & 1.915 & 3 & 0.24 \\
\hline Agriculture & South & shoulder & Ashan & $03 / 11 / 2014$ & 24.72 & 18 & 57.28 & 17.18 & 4 & 0.432 & 3 & 0.26 \\
\hline Agriculture & South & Back slope & Ashan & $03 / 11 / 2014$ & 35.28 & 24 & 40.72 & 22.22 & 4 & 0.011 & 6 & 0.30 \\
\hline Agriculture & South & Foot slope & Ashan & $03 / 11 / 2014$ & 39.28 & 30 & 30.72 & 13.22 & 3 & 0.735 & 4 & 0.22 \\
\hline Agriculture & South & Toe slope & Ashan & $03 / 11 / 2014$ & 17.44 & 36.56 & 46 & 13.80 & 2 & 1.5 & 3 & 0.29 \\
\hline Agriculture & East & summit & Ashan & $01 / 11 / 2014$ & 15.28 & 24 & 60.72 & 18.22 & 2 & 0.975 & 2 & 0.26 \\
\hline Agriculture & East & shoulder & Ashan & $01 / 11 / 2014$ & 20.72 & 12.72 & 66.56 & 32.97 & 4 & 0.495 & 4 & 0.34 \\
\hline Agriculture & East & Back slope & Ashan & $01 / 11 / 2014$ & 20.72 & 14 & 65.28 & 35.58 & 4 & 0.275 & 5 & 0.37 \\
\hline Agriculture & East & Foot slope & Ashan & $01 / 11 / 2014$ & 11.28 & 12 & 76.72 & 23.02 & 2 & 0.625 & 4 & 0.23 \\
\hline Agriculture & East & Toe slope & Ashan & $01 / 11 / 2014$ & 16.56 & 11.84 & 71.6 & 21.48 & 3 & 0.825 & 3 & 0.23 \\
\hline Agriculture & West & summit & Ashan & $01 / 11 / 2014$ & 23.44 & 24.56 & 52 & 15.60 & 3 & 0.755 & 3 & 0.26 \\
\hline Agriculture & West & shoulder & Ashan & $01 / 11 / 2014$ & 16.16 & 30 & 53.84 & 16.15 & 4 & 0.59 & 4 & 0.36 \\
\hline Agriculture & West & Back slope & Ashan & $01 / 11 / 2014$ & 18 & 18.72 & 63.28 & 28.98 & 4 & 0.19 & 6 & 0.37 \\
\hline Agriculture & West & Foot slope & Ashan & $01 / 11 / 2014$ & 18.56 & 9.84 & 71.6 & 21.48 & 3 & 0.645 & 3 & 0.26 \\
\hline Agriculture & West & Toe slope & Ashan & $01 / 11 / 2014$ & 19.28 & 10 & 70.72 & 21.22 & 3 & 1.875 & 2 & 0.19 \\
\hline Range & North & summit & Heris & $30 / 10 / 2014$ & 18.2 & 19.64 & 62.16 & 18.65 & 1 & 1.99 & 2 & 0.17 \\
\hline Range & North & shoulder & Heris & $30 / 10 / 2014$ & 14.16 & 24 & 61.84 & 16.55 & 2 & 1.58 & 3 & 0.24 \\
\hline Range & North & Back slope & Heris & $30 / 10 / 2014$ & 18.56 & 16.16 & 65.28 & 27.58 & 3 & 0.64 & 4 & 0.30 \\
\hline Range & North & Foot slope & Heris & $30 / 10 / 2014$ & 16.4 & 24.32 & 59.28 & 17.78 & 2 & 1.3 & 3 & 0.25 \\
\hline Range & North & Toe slope & Heris & $30 / 10 / 2014$ & 14.4 & 13.44 & 72.16 & 18.65 & 2 & 1.79 & 2 & 0.18 \\
\hline Range & South & summit & Ashan & $01 / 11 / 2014$ & 23.44 & 12.72 & 63.84 & 19.15 & 2 & 1.7 & 2 & 0.16 \\
\hline Range & South & shoulder & Ashan & $01 / 11 / 2014$ & 11.44 & 28.72 & 59.84 & 6.95 & 3 & 1.5 & 3 & 0.25 \\
\hline Range & South & Back slope & Ashan & $01 / 11 / 2014$ & 8.16 & 34.72 & 57.12 & 7.14 & 2 & 1.325 & 4 & 0.27 \\
\hline Range & South & Foot slope & Ashan & $01 / 11 / 2014$ & 29.84 & 18.56 & 51.6 & 25.48 & 2 & 1.525 & 3 & 0.21 \\
\hline Range & South & Toe slope & Ashan & $01 / 11 / 2014$ & 20 & 33.44 & 46.56 & 8.97 & 1 & 1.815 & 2 & 0.19 \\
\hline Range & East & summit & Ashan & $03 / 11 / 2014$ & 15.28 & 24 & 60.72 & 18.22 & 1 & 2.05 & 2 & 0.20 \\
\hline Range & East & shoulder & Ashan & $03 / 11 / 2014$ & 8 & 22.56 & 69.44 & 20.83 & 1 & 1.9 & 5 & 0.24 \\
\hline Range & East & Back slope & Ashan & $03 / 11 / 2014$ & 49.44 & 21.28 & 29.28 & 28.78 & 3 & 0.415 & 4 & 0.22 \\
\hline Range & East & Foot slope & Ashan & $03 / 11 / 2014$ & 46.72 & 21.28 & 32 & 25.60 & 2 & 1.45 & 3 & 0.17 \\
\hline Range & East & Toe slope & Ashan & $03 / 11 / 2014$ & 19.44 & 30.16 & 50.4 & 5.12 & 2 & 2.815 & 2 & 0.17 \\
\hline Range & West & summit & Heris & $02 / 11 / 2014$ & 26.72 & 18 & 55.28 & 16.58 & 2 & 1.998 & 3 & 0.16 \\
\hline Range & West & shoulder & Heris & $02 / 11 / 2014$ & 35.44 & 5.28 & 59.28 & 27.78 & 4 & 1.65 & 3 & 0.20 \\
\hline Range & West & Back slope & Heris & $02 / 11 / 2014$ & 49.44 & 14 & 36.56 & 39.97 & 3 & 0.44195 & 4 & 0.23 \\
\hline Range & West & Foot slope & Heris & $02 / 11 / 2014$ & 19.44 & 32 & 48.56 & 10.57 & 2 & 2.585 & 3 & 0.21 \\
\hline Range & West & Toe slope & Heris & $02 / 11 / 2014$ & 45.28 & 24.72 & 30 & 29.00 & 1 & 1.905 & 2 & 0.16 \\
\hline
\end{tabular}

in the laboratory using the hydrometer method (Bouyoucos 1962), which is very accurate (Hank and Ashcroft 1970). Another parameter required for determining soil erosion, is organic carbon, which was obtained using the Walkie-Black method (Skjemstad and Baldock 2007). In this method, particles smaller than $2 \mathrm{~mm}$ were used for determining the organic carbon in soil and soil particles larger than $2 \mathrm{~mm}$ were weighed, divided by the total weight of the soil and then multiplied by 0.3 in order to determine the quantity of very fine sand in each sample. The erodibil- 
ity values were analyzed using ANOVA and SPSS software and map processing was done using ArcGIS software.

\section{Soil erodibility factor (K)}

The measurement of erodibility is a sophisticated process because sensitivity of soil to erosion can vary depending on environmental conditions and many other factors such as physical, chemical, mineral, and biological properties, vegetation and depth of the soil. On the other hand, direct measurement of erodibility requires long term data, which is time-consuming but there are many ways of determining erodibility using more easily available soil properties (Zhang et al. 2008). The properties of soil included in the erodibility factor (K-factor) are organic material, stability of soil particles, soil permeability and chemical composition, which can be measured and are indicators of soil erosion (Zhang et al. 2007). One of the most common experimental models that is widely used to investigate the amount of erosion by water is the USLE Model; this model is used to estimate soil loss from farmland due to surface and rill erosion (Schiettecatte et al. 2008). In this model, the erodibility is estimated based on the coarse sand, silt and very fine sand, organic matter, structure and permeability of soil (Wischmeier et al. 1978).

Soil erodibility is determined using the K-factor and intrinsic properties of the soil.

$\mathrm{K}$-factor formula is expressed in equations (1) and (2) below (Wischmeier et al. 1978):

$$
\begin{aligned}
k= & \left(0.00021 \times M^{1.14} \times(12-a)+3.25 \times(b-2)+\right. \\
& \left.+3.3 \times 10^{-3}(c-3)\right) / 100 \\
M= & (\% \text { Silt }+\% \text { very fine sand }) \times(100-\% \text { clay })
\end{aligned}
$$

where: $M$ is particle size, $a$ is percentage of organic matter, $b$ is soil structure code where sand $(1=<5 \% ; 2=5-15 \%$; $3=15-50 \% ; 4=>50 \%), c$ is permeability of soil profile in saturated hydraulic conductivity. In terms of permeability, 1 = fast (150 mm per hour), 2 = moderate or fast (50 to $150 \mathrm{~mm}$ per hour), $3=$ moderate $(12$ to $50 \mathrm{~mm}$ per hour), $4=$ low to moderate ( 5 to $15 \mathrm{~mm}$ per hour), $5=$ low ( 1 to $5 \mathrm{~mm}$ per hour), 6 very low ( $1 \mathrm{~mm}$ per hour). The soil particles are graded based on their size: for fine sand particles $0.05-0.10 \mathrm{~mm}$, for silt $0.002-0.05 \mathrm{~mm}$, and for clay $0.002 \mathrm{~mm}$, organic matter content is calculated using the organic carbon content and a constant of 1.72 . Following the measurement of all these parameters in the laboratory, the relevant values are placed in equation 1 and soil erodibility is obtained.

\section{Results and Discussion}

Two-way ANOVA statistical test was used to determine the significant differences among groups shown in Table 1. Given what was described earlier, these tests have a high power in showing within group and among group differences in erodibility. With respect to Table 2, the two-way ANOVA test revealed a significant difference in the data.

In Table 2, the results of the analysis confirm that there is erosion associated with both land use and landform both are less than 0.000 , which indicate a significant difference. According to Fig. 5a, mean quantity of silt on agricultural land is higher than on pastures. Very fine sand on agricultural land is the same as on pastures. But percentage of very fine sand is higher on the back slopes. Fig. 6 indicates the percentage of organic matter recorded in soil from areas with different land uses. There is little organic matter (\%) on the back slopes subject to both land uses (Fig. 6). Organic matter (\%) in pastures is higher than in cultivated land. Silt (\%) is higher in agricultural land than in pastures with low erodibility. The results of the discriminant function analysis (DFA) recorded in Table 3 indicate the discriminatory power of land use and landform components in terms of erodibility. According to Table 3, the $\mathrm{K}$ factor is able to discriminate between differences in land use (Agriculture, Pasture) and landform components with a significances of 0.000 and 0.002 , respectively. Aspect as a treatment was not discriminated by the DFA and erodibility did not separate different aspects from each other.

Table 2 Two-way ANOVA of soil erodibility factors (K) associated with land use and landform.

\begin{tabular}{|l|c|c|c|c|c|c|}
\hline \multicolumn{1}{|c|}{ Source } & $\begin{array}{c}\text { Type III } \\
\text { Sum of } \\
\text { Squares }\end{array}$ & $\mathbf{d f}$ & $\begin{array}{c}\text { Mean } \\
\text { Square }\end{array}$ & F & Sig. & $\begin{array}{c}\text { Partial } \\
\text { Eta } \\
\text { Squared }\end{array}$ \\
\hline $\begin{array}{l}\text { Corrected } \\
\text { Mxxodel }\end{array}$ & 0.119 a & 9 & 0.013 & 14.071 & 0.000 & 0.808 \\
\hline Intercept & 2.440 & 1 & 2.440 & 2596.128 & 0.000 & 0.989 \\
\hline Land use & 0.058 & 1 & 0.058 & 61.447 & 0.000 & 0.672 \\
\hline Landform & 0.055 & 4 & 0.014 & 14.665 & 0.000 & 0.662 \\
\hline $\begin{array}{l}\text { Land use } \\
\text { * land- } \\
\text { form }\end{array}$ & 0.006 & 4 & 0.002 & 1.633 & 0.192 & 0.179 \\
\hline Error & 0.028 & 30 & 0.001 & & & \\
\hline Total & 2.588 & 40 & & & & \\
\hline $\begin{array}{l}\text { Corrected } \\
\text { Total }\end{array}$ & 0.147 & 39 & & & & \\
\hline
\end{tabular}

a $\mathrm{R}$ Squared $=0.808$ (Adjusted R Squared $=0.751$ )

Table 3 Discriminant function analysis of soil erodibility factors (K) associated with land use, aspect and landform.

\begin{tabular}{|l|c|c|c|}
\hline \multicolumn{1}{|c|}{ Test of functions } & Wilks lambda & Chi square & Sig \\
\hline Land use & 0.608 & 18.67 & 0.000 \\
\hline Aspect & 0.96 & 1.23 & 0.74 \\
\hline Landform components & 0.62 & 16.89 & 0.002 \\
\hline
\end{tabular}

\section{Soil properties}

\section{Texture and structure of soils}

Soil texture is determined by the percentage by weight of sand, silt and clay particles in the soil. Size of sand particles are about $0.05-2 \mathrm{~mm}$, silt particles about 
0.05-0.002 mm, clay particles are smaller than 0.002 . Soils with medium textures (loams) are highly erodible due to the large amount of silt and very fine sand and small particles (silts and clays) they contain, which are easily transported by water (O'Geen and Schwankl 2006). When measuring soil erodibility, silt and clay content are the main elements in the distribution of particle size. With increasing clay, the viscosity and resistance of soil particles are enhanced and the soil becomes more resistant to erosion. Soils with a high sand content are also more resistant to erosion because sand increases soil porosity and improves soil permeability. A soil with a high volume of silt has little resistance to erosion and is therefore susceptible to erosion (Thang 2002). According to Fig. 5b, there is less very fine sand at the summits than at other positions on the hillslopes; on the other hand, average percentage of very fine sand in foot-slope soils is higher than in soils at other positions on hillslopes. In Fig. 5b, a particular trend is seen in the amount of very fine sand, which occurs in both agricultural and pastoral land. The parent material in this region is divided into two parts a lower and upper: the lower part contains a sequence of tuffs and altered tuffs, sand and compressed sand and the upper part is much thicker and contains tuff marl, tuff, siltstone, volcanic stones, conglomerate and river sediments and rounded rubble and cross bedding. Standard deviations for both shoulder landforms is the lowest; while in the foot-slope landform, both average and standard deviations are higher than for other landforms. According to Fig. 7, the erodibility of back slope landform is higher than other landforms and this trend is repeated in both agricultural and pastoral land. According to Fig. 5b, the percentage of very fine sand in back slope soils under both land uses is the highest and this is regarded as a good indicator of the relationship between erodibility and very fine sand. Fig. 5 reveals that the average for all pastoral land is less than for agriculture land. The conditions on hillslopes can differ considerably over short distances, which reflects the complexity of the relations among factors.

\section{Soil permeability}

The terms permeability and permeation have many different definitions. Permeation describes the diffusion of water into soil while permeability is the ease with which water or any liquid move inside soils (O'Geen and Schwankl 2006). According to the studies of Wischmeier and Mannering (1969), there is a simple linear regression between permeability, runoff, amount of soil in runoff and loss of soil for soils with various properties; therefore, permeability has a critical role in the erosion of soil (Wischmeier and Mannering 1969). In Fig. 5a, the silt content of soils from agriculture land in all 5 landforms was higher than in pastoral land; so the rate of erosion of agriculture land is estimated to be higher than that of pastoral land. Foot slope and toe slope soils used for agriculture have the least and the highest content of silt, and summit and toe slope soils used for pasture have the
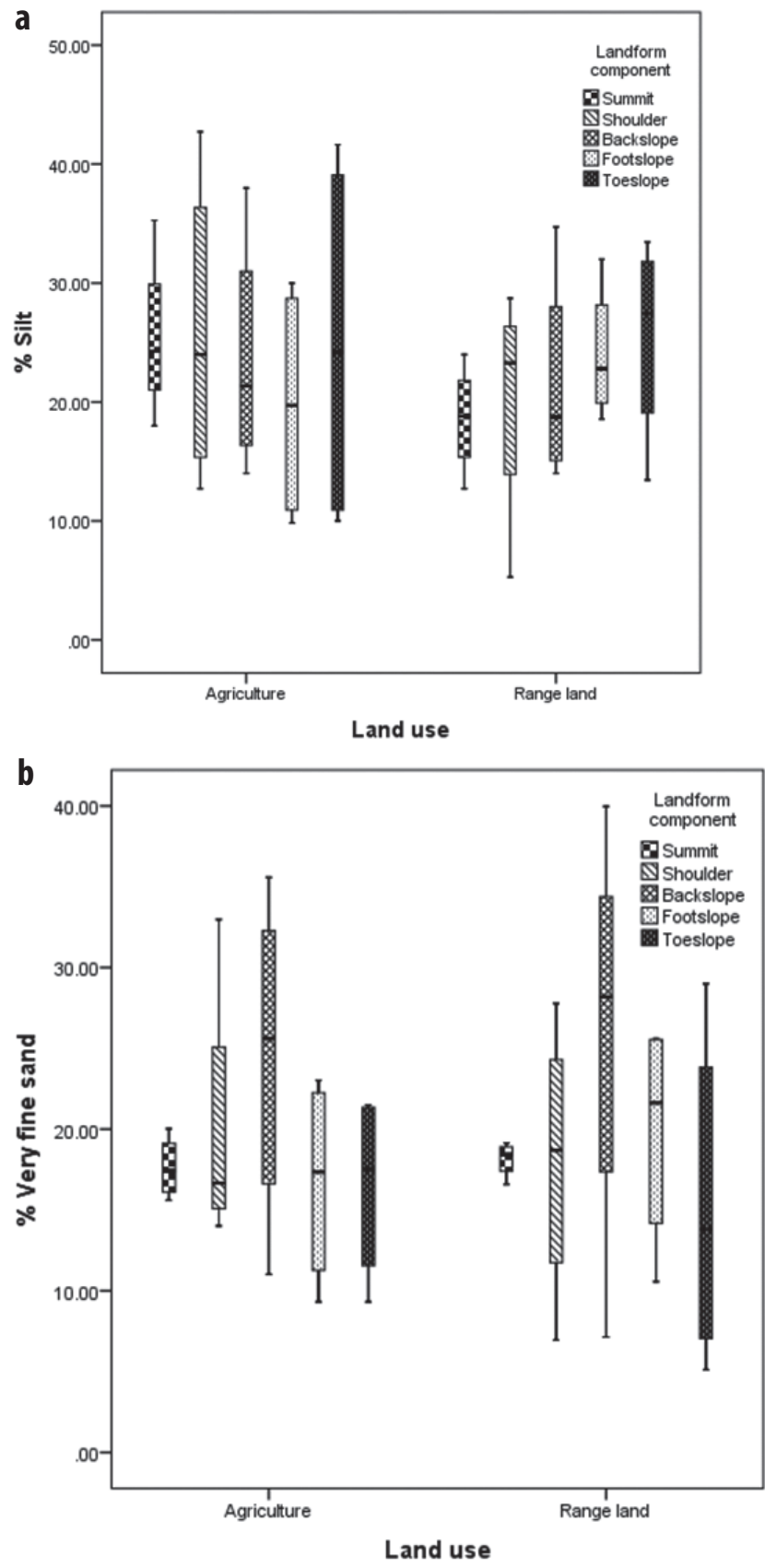

Fig. 5 Box plot of silt in soil (a) and very fine sand (b) collected at different positions on hillslopes.

least and highest silt content, respectively (Fig. 5a). Permeability of soil with silt is less than soil with very fine sand and therefore subject to greater erosion. Meanwhile, according to Figs. 5a and 7a soils with a high silt content, such as toe slope and back slope soils, are at high risk of erosion. Scientifically speaking, soils that have a high silt and low organic matter content, in contrast, have high erodibility. The percentage of silt, clay and sand reflects the current status of the physical and chemical properties of the soils and very fine sand particles (0.1-0.05) have a similar behaviour to silt during erosion (Wischmeier and Mannering 1969). Experimental analysis of the soil samples revealed that the soils in the drainage basin have a clay-loamy, silty-loamy and silty-loamy-clay texture 


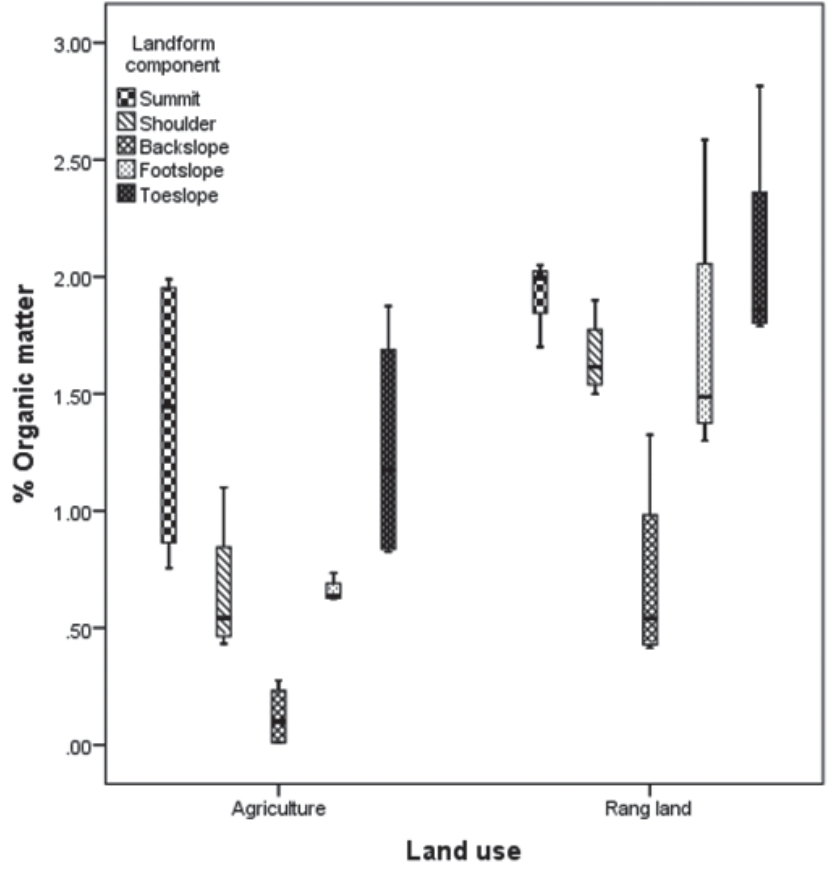

Fig. 6 Box plot of the organic matter in soils collected at different positions on hillslopes.

generally (Table 1). Consequently, the highest permeability was recorded for foot and toe slope soils, which is consistent with the erodibility results in Fig. 7 a.

\section{Soil organic material}

Organic carbon storage is one of the valuable natural resources that determines the physical, chemical and biological processes in the soil and improves soil quality (Carter 2007). The depletion of soil organic carbon results in deterioration of the soil, increase in erosion and decrease in production. Organic matter in the soil prevents the breakdown of soil aggregates, decreases soil erodibility, increases water-holding capacity, increases soil permeability and improves soil structure. Dynamics of soil organic carbon is associated with the distribution of nutrients and transport of sediments both temporally and spatially (Schiettecatte et al. 2008). Nutrients such as phosphorous can be leached from a drainage basin together with sediments by river processes, and plant material and humus can affect soil erosion by providing a protective layer against the erosive effects of rain drops and the drainage processes; thus, understanding the spatial and temporal dynamics of soil organic carbon and dynamics and sedimentation of soil organic carbon is important (Van Oost et al. 2005). On the other hand, the location and properties of the land with respect to the curvature and slope of the hillslopes is a critical factor in the variability of soil organic carbon ( $\mathrm{Li}$ et al. 2007). As in Fig. 6, the maximum amount of organic matter was recorded in the soils at the summit and in toe slopes, and the lowest value in back slope soils; these results are consistent with the findings of $\mathrm{Li}$ and Luo 2006 and $\mathrm{Li}$ et al. 2007. The carbon concentration in the topography,
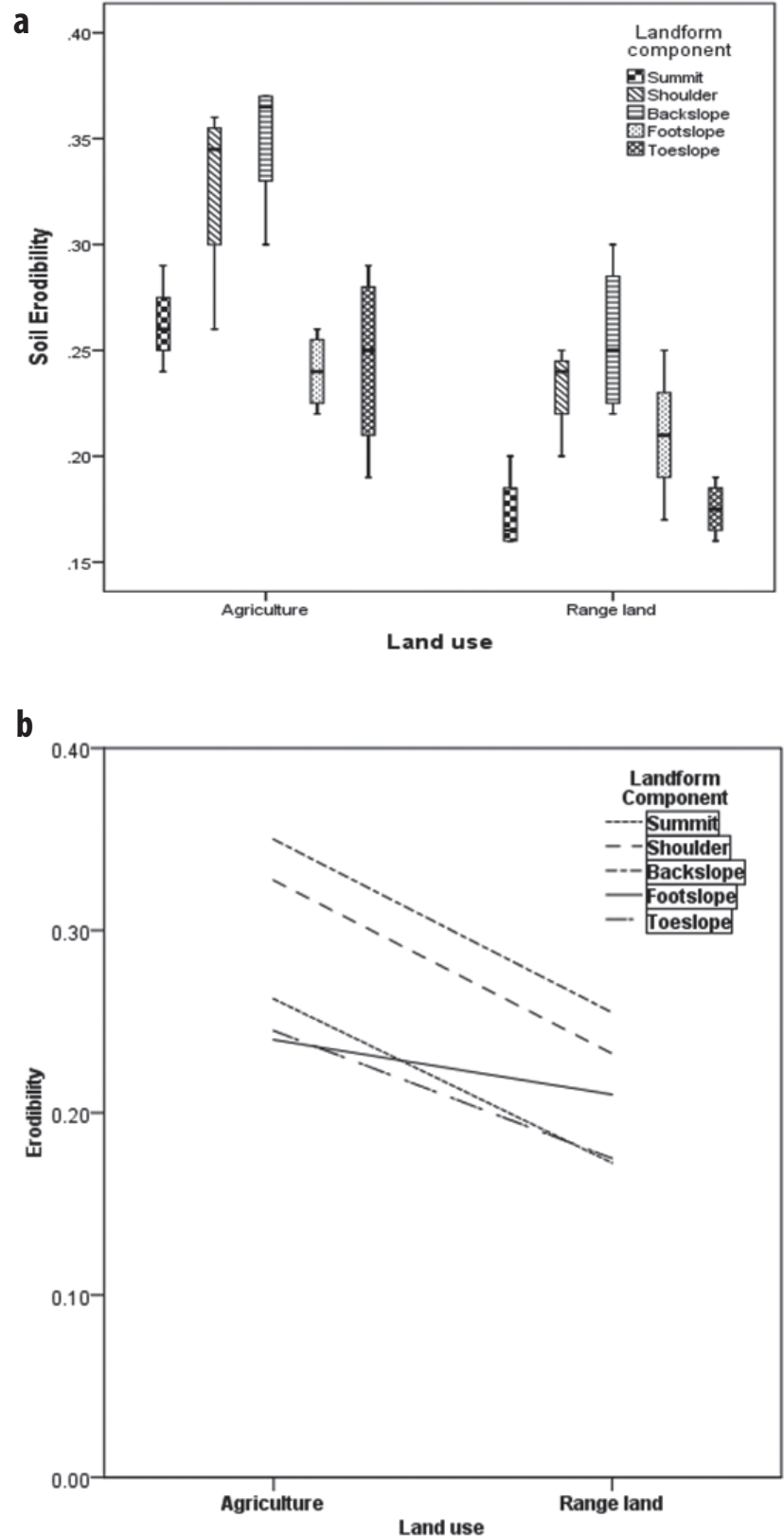

Fig. 7 Box plot of k factor with land use and position on hillslopes (a) and (b).

therefore, can be modelled and the results of this study confirms the above fact. According to the results, the $\mathrm{K}$ factor has a polynomial relationship with organic matter. The equation extracted from this relationship is given below and has an $R^{2}$ of 0.87 .

$y=-0.0576 x+0.3174$

In the above equation, $x$ is organic carbon and $y$ is erodibility. In this equation, coefficient $x$ is negative; this means that increasing organic matter reduces erodibility of soils. Equation (3) is based on samples from a particular area and the results may not be relevant to other regions. The photograph of this region support the results of this research (Figs. 8a and 8b). 

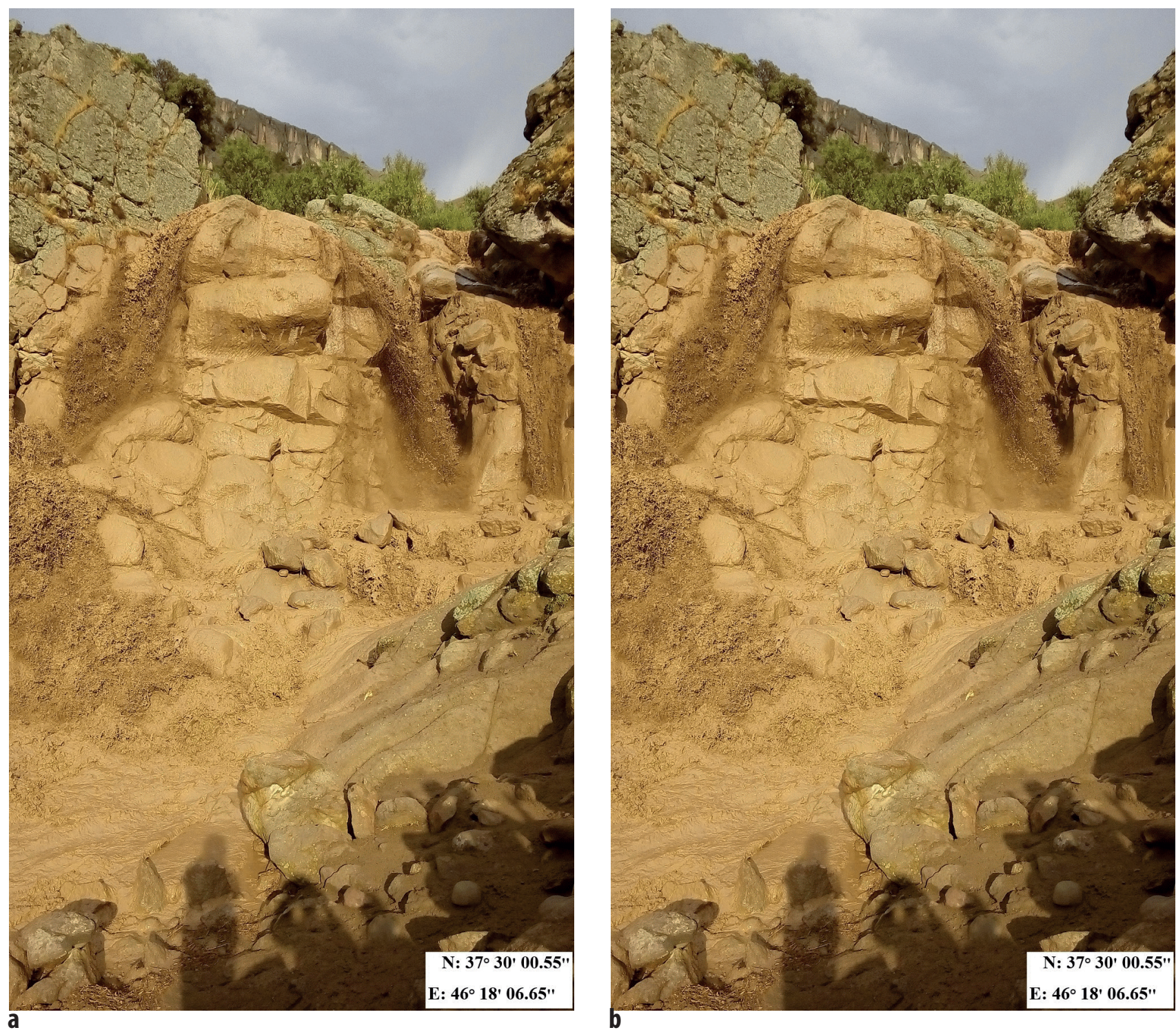

Fig. 8 Photographs of the Ashan drainage basin with geographical coordinates.

\section{The relationship between the erodibility variables}

Hillslope positions 2 and 3, i.e. shoulder and back slope agricultural and pastoral soils, are subject to the greatest erosion and those at the summit the least erosion. Foot slope and toe slope soils are subject to the least erosion according to Figs. 7a and 7b. Rate of erosion decreases from land use 1, agriculture, to land use 2, pasture. In the studies conducted by Wischmeier and Mannering (1969) on 55 soil samples, soil permeability decreases with decrease in the amount of organic matter, sand, aggregate index, density and increase in the percentage of sand and silt, percentage of suspended solids and $\mathrm{pH}$, while in the studies of Middleton (1903), the percentage of suspended solids is closely related to only erodibility (Middleton 1903; Wischmeier and Mannering 1969). In this study, the rate of erodibility is significantly associated with organic matter content in both land uses and the minimum content of organic matter was recorded in soils of back slopes subject to both landform uses (Fig. 6 and Equation (3)). There is a significant relationship between erosion and very fine sand (Figs. 5b, 7a and 7b), so toe slope soils subject to both landform uses have a high very fine sand content, whereas the least erodibility is associated with toe slope soils used for agriculture and summit soils used for pasture. Ashan drainage basin is mountainous and slopes are very steep in most areas (Fig. 4) and because erodibility can be affected by topography; according to Table 1 , erosion occurs at all the positions on the hillslopes under both forms of land use, therefore, other factors such as topography (slope and aspect) also have an effect on erodibility.

\section{Conclusion}

The results of this research indicate that there is a strong relationship between land use, soil properties and landform components, and erodibility of hillslopes. Silt content of soil is strongly positively associated with its erodibility. According to the results, erodibility is higher in agricultural land than pastures. On the other 
hand, the back slopes of hillslopes, are subject to greater levels of erosion than the other positions on hillslopes. In back slope soils, the organic matter is less than at other positions on hillslopes and the maximum amount of organic matter in back slope soils is similar to that recorded at the summit. Therefore, soils with a high amount of organic matter are less subject to erosion than soils with a low organic matter content. There was no relationship between erodibility and the aspect of a hillslope.

\section{REFERENCES}

Agassi M (1996) Soil erosion, conservation, and rehabilitation. Marcel Dekker

Bahrami HA, Pornalkh T, Tahmasebipoor N (2005) Study of soil erodibility in different land uses from Chamanjir watershed. Proceedings of the Third National Conference of Erosion and Sediment, pp 505-510.

Bennett HH (1926) Some copparison of the properties of humid-tropical and humid-pempreture american soils; with spatial reference to indicated relations between chemical composition and physical properties. Soil Sci 21: 349-376.

Bryan RB (1968) The development, use and efficiency of indices of soil erodibility. Geoderma 2: 5-26.

Bryan RB (1991) Surface wash processes. In: Slaymaker O (ed) Field Experiments and Measurement Programs in Geo-morphology. Balkema and UBC Press. Vancouver 107-169.

Bouyoucos GJ (1962) Hydrometer method improved for making particle size analyses of soils. Agron J 54: 464-465.

Carter RM (2007) The myth of dangerous human-caused climate change. Australasian Institute of Mining and. In Metallurgy. New Leaders Conference. Brisbane. Conference Proceedings.

Chorley RJ (1959) The geomorphic significance of some Oxford soil. Am J Sci 257: 503-515.

De Ploey J, Poesen J (1985) Aggregate stability, runoff genera-tion and interrill erosion. In: Richards, KS, Arnett RR, Ellis S (eds) Geomorphology and Soils. George Allen and Unwin. London, pp 99-120.

Ghaderi N, Ghoddosi J (2005) Study of soil erodibility in lands units from Telvarchai watershed. Proceedings of the Third National Conference of Erosion and Sediment (In Persian). Tehran. Iran, 367-372.

Hank RJ, Ashcroft GL (1970) Physical properties of soil: The role of geomorphology and soil erosion in an undisturbed environment. Logan, Utah.

Climatology map (2014) Iran Meteorological Organization.

IWRM (2009) Iran Water Resources Management Company website. Retrieved December 15. 2009 at www.wrm.ir.

Kirkby MJ, Morgan RPC (1980) Soil erosion. John Wiley and Sons, Ltd.

Lal R (1990) Soil erosion in the tropics: principles and management. McGraw Hill.

Li ZG, Luo ZD (2006) On method for evaluating soil erosion severity in county scale-index of soil erosion severity and its application. Bull Soil Water Conserv 26: 41-51.
Li J, Okin GS, Alvarez L, Epstein H (2007) Quantitative effects of vegetation cover on wind erosion and soil nutrient loss in a desert grassland of southern New Mexico. USA. Biogeochemistry 85: 317-332.

Middleton HE (1903) Properties of soils which influence soil erosion.

National Cartography Organization (2011) Topography map. Tehran. Iran.

Nosrati K, Feiznia S, Van Den Eeckhaut M, Duiker SW (2011) Assessment of soil erodibility in Taleghan Drainage Basin, Iran, using multivariate statistics. Phys Geog 32: 78-96.

O'Geen AT, Schwankl LJ (2006) Understanding soil erosion in irrigated agriculture. Publ. 8196. Univ of California Department of Agriculture and National Resources.

Renard KG, Foster GR, Weesies GA, McCool DK, Yoder DC (1997) Predicting soil erosion by water: a guide to conservation planning with the revised universal soil loss equation (RUSLE). Agriculture Handbook (Washington). 703.

Romkens MJM (1985) The soil erodibility factor: a perspective. Soil erosion and conservation, pp 445-461.

Ruhe RV (1960) Elements of the soil landscape. In Trans. 7th int. Congr Soil Sci 4: 165-170.

Schiettecatte W, Gabriëls D, Cornelis WM, Hofman G (2008) Impact of deposition on the enrichment of organic carbon in eroded sediment. Catena 72: 340-347.

kjemstad JO, Baldock JA (2007) Total and organic carbon. Soil sampling and methods of analysis. 2nd ed. CRC Press. Boca Raton. FL, pp 225-238.

Smith DD, Wischmeier WH (1962) Rainfall erosion. Adv Agron 14: $109-148$

Thang HC (2002) Development and application of criteria and indicators for sustainable forest management, including forest management certification and products labeling in Malaysia - a case study. Paper presented at theWorkshop on the Development of Brunei Darussalam. Criteria and Indicators for Sustainable Forest Management. Bandar Seri Begawan. Brunei Darunssalam, pp 25-28.

Veihe A, Hasholt B, Schiøtz IG (2003) Soil erosion in Denmark: processes and politics. Environ Sci Policy 6: 37-50.

Van Oost K, Govers G, Quine TA, Heckrath G, Olesen JE, De Gryze S, Merckx R (2005) Landscape-scale modeling of carbon cycling under the impact of soil redistribution: The role of tillage erosion. Glob Biogeochem Cycles 19.

Wischmeier WH, Mannering JV (1969) Relation of soil properties to its erodibility. Soil Sci Soc Am J 33: 131-137.

Wischmeier WH, Smith DD (1978) Predicting rainfall erosion losses: A guide to conservation planning. USDA, Washington, D.C.

Young RA, Römkens MJ, McCool DK (1990) Temporal variations in soil erodibility. Catena, Supplement: 41-53.

Zhang ZG, Fan BE, Bai WJ, Jiao, JY (2007) Soil anti-erodibility of plant communities on the removal lands in hilly-gully region of the Loess Plateau. Sci Soil Water Conserve 5: 7-13.

Zhang KL, Shu, AP, Xu, XL, Yang, QK, Yu, B (2008) Soil erodibility and its estimation for agricultural soils in China. J Arid Environ 72: 1002-1011. 